\title{
The Effect of Diet Coke and Monosodium Glutamate on the Cerebellar Cortex of Adult Male Albino Rats. Histological and Immuno-histochemical Study
}

Original

Noha Ali Abd El-Latif Abd El-Wahed, Esmat Zaki Geith, Nagwa Kostandy Kalleny, Hadwa Ali Abd Al-Khalek

Department of Histology and Cell biology, Faculty of Medicine, Ain Shams University

\begin{abstract}
Background: The consumption of fast- food is increasing among children, adolescents and adults. Carbonated drinks as Diet Coke are widely consumed with fast food. One of the thousands of chemicals used in our new high-tech foods is the monosodium glutamate (MSG).

Aim of the study: This study was conducted to investigate the effect of Diet Coke and monosodium glutamate salt either separately or in combination on the cerebellar cortex of adult male albino rats.

Materials and Methods: Forty adult male albino rats were divided into four groups. Group I: control group. Group II (Diet Coke group) which was subdivided into: subgroup IIA: each rat received $2.5 \mathrm{ml}$ of Diet Coke twice daily by oral gavage and subgroup IIB: rats received Diet Coke instead of water throughout the day. Group III (MSG group): rats received MSG salt solution ( $3 \mathrm{gm} \mathrm{MSG} / \mathrm{kgm}$ ) by oral gavage once daily. Group IV (combination group) rats received combination of MSG solution and Diet Coke. This group was subdivided into two subgroups. Subgroup IVA: rats received MSG salt solution in the same dose as group III and $2.5 \mathrm{ml}$ of Diet Coke twice daily, by oral gavage. Subgroup IVB: rats received MSG salt solution in the same dose as group III and Diet Coke instead of water throughout the day. At the end of the experiment (21 days) cerebella were dissected out and processed for histological, immunohistochemical and morphometric studies.

Results: Histological examination of the cerebellar cortex revealed that both Diet Coke and MSG either separately or in combination resulted in degenerative changes that were more significant in the combination group.

Conclusion: Diet Coke and MSG induced degenerative changes in the cerebellar cortex that was more significant in their combination.
\end{abstract}

Received: 17 January 2019, Accepted: 02 February 2019

Key Words: Cerebellum, diet coke, MSG.

Corresponding Author: Hadwa Ali Abd El-Khalek, MD, Department of Histology and Cell biology, Faculty of Medicine, Ain Shams University, Egypt, Tel.: +20 227546265, E-mail: hadwa.ali@gmail.com

ISSN: $1110-0559$, Vol. 42, No. 2

\section{INTRODUCTION}

Children and adolescents are increasingly consuming food away from home, particularly from fast sources. The upward trends in fast-food consumption have paralleled increasing obesity rates among children and adolescents. In addition, fast food consumption has been associated with greater total energy intake and poorer nutrient intake $\mathrm{e}^{[1]}$.

Carbonated drinks are the second most consumed beverages in the world. Coca-Cola, the first cola drink was invented in Atlanta by John Pemberton in 1886. Today products of the Coca-Cola Company are consumed at the rate of more than one billion drinks per day ${ }^{[2]}$. Carbonated drinks are widely consumed with fast food. They are also exist in the form of diet drinks, for example Diet Coke ${ }^{\circledR}$ and Diet Pepsi ${ }^{\mathbb{E}[3]}$.

According to company specifications, Coca Cola ${ }^{\mathrm{TM}}$ is a carbonated water solution containing in $100 \mathrm{ml}$ : Carbohydrate $10.6 \mathrm{~g}$, sodium $7 \mathrm{mg}$, caffeine $11.5 \mathrm{mg}$, caramel, phosphoric acid, citric acid, vanilla extract, natural flavorings (orange, lemon, nutmeg, cinnamon, coriander), lime juice and fluid extract of coca. The only difference between regular Cola and light cola is replacement of carbohydrates with non-nutritive sweetener, aspartame $(24 \mathrm{mg} / 100 \mathrm{ml})^{[4]}$. Aspartame might result in memory loss and behavioral changes ${ }^{[5]}$.

Monosodium glutamate (MSG) is one of the most applied food additives in the modern food all over the world. It is the sodium salt of glutamic acids which is used as a flavor enhancer ${ }^{[6]}$. Monosodium glutamate is added either as a purified monosodium salt or as a component of a mix of amino acids and small peptides. Glutamate is the main excitatory neurotransmitter in the mammalian central nervous system stimulating glutamate receptors and plays important roles in both physiological and pathological processes ${ }^{[7]}$. Although many Food and Drug Control Agencies have certified MSG to be safe for human consumption without any specified dosage ${ }^{[8]}$, experimental findings have linked the intake of MSG with a number of neurodegenerative and neurobehavioral changes ${ }^{[9]}$. 


\section{AIM OF THE WORK}

The aim of this work was to investigate the effect of Diet Coke and monosodium glutamate salt either separately or in combination on the cerebellar cortex of adult male albino rats.

\section{MATERIALS AND METHODS}

\section{(A) Materials used}

\section{Monosodium Glutamate (MSG) salt}

Monosodium Glutamate was obtained in the form of white crystals. It was purchased from the market, Cairo, Egypt. It was prepared by dissolving the salt in distilled water ${ }^{[10]}$. It was administrated in a dose of $3 \mathrm{gm} / \mathrm{kgm}$ body weight $/$ day ${ }^{[1]}$ by oral gavage via metal intragastric tube for 21 days.

\section{Diet Coke}

It was purchased from the market, Cairo, Egypt. Diet Coke was de-gassed by intense shaking and kept at room temperature $^{[12]}$. It was administrated either twice daily by oral gavage in a volume of $2.5 \mathrm{ml}$ to identify the effect of limited amount of coke intake; or Diet Coke replacing water was allowed freely for drinking throughout the day for 21 days according to grouping ${ }^{[13]}$.

\section{(B) Animals}

Forty adult male albino rats of average weight $200 \mathrm{gm}$ were used in this study. They were divided into four groups. They were purchased from the Medical Research Centre, Faculty of Medicine, Ain Shams University. They were kept in wire mesh cages under proper sanitary conditions with proper conditions of light and temperature. The whole experiment was carried out in the Medical Research Centre, Faculty of Medicine, Ain Shams University; in accordance with the animal care and use guidelines of the Scientific Research Ethical Committee. The animals were fed on balanced rat chow. The bodies of the dead animals were disposed of by using the incinerator. Animals were classified into the following groups:

\section{Group I (Control Group): (15 rats)}

- Subgroup IA: (5 rats) rats had free access to food and water.

- Subgroup IB: (5 rats) each rat was administrated $2.5 \mathrm{ml}$ of distilled water twice daily by oral gavage. Rats had free access to food and water.

- Subgroup IC: (5 rats) each rat was administrated $0.5 \mathrm{ml}$ of distilled water once daily by oral gavage. Rats had free access to food and water.

\section{Group II (Diet Coke Group): (10rats):}

- Subgroup IIA: (5 rats) each rat was given $2.5 \mathrm{ml}$ of Diet Coke twice daily, 6 hours apart, by oral gavage. Rats had free access to food and water.

- Subgroup IIB: (5 rats) rats of this subgroup received Diet Coke instead of water for drinking throughout the day and the average amount of Diet Coke intake / rat was calculated daily. Rats had free access to ordinary food.

\section{Group III (Monosodium glutamate Group): (5 rats)}

Rats of this group received $3 \mathrm{gm} \mathrm{MSG} \mathrm{/} \mathrm{kgm} \mathrm{by} \mathrm{oral}$ gavage once daily. Each rat received the calculated dose of MSG salt dissolved in $0.5 \mathrm{ml}$ of distilled water. Rats had free access to food and water.

\section{Group IV (Combination Group): (10 rats)}

Rats of this group received a combination of MSG solution and Diet Coke. It was further subdivided into:

- Subgroup IV A: (5 rats)

Rats of this subgroup received MSG as in group III. In addition, $2.5 \mathrm{ml}$ of Diet Coke was administered twice daily by oral gavage. Rats had free access to food and water.

- Subgroup IV B: (5 rats)

Rats of this subgroup received MSG as in group III. In addition, water was replaced by Diet Coke for drinking throughout the day and the average amount of Diet Coke intake / rat was calculated daily. Rats had free access to ordinary food.

Measurement of rat body weight: the body weight of each rat in all groups was measured at the beginning and at the end of the experiment. Statistical study on the mean weight was done.

At the end of the experimental periods, the animals were sacrificed by decapitation under general anaesthesia by thiopental sodium administrated intra-peritoneally at a dose of $30 \mathrm{mg} / \mathrm{kgm}^{[14]}$. Their cerebella were dissected. The cerebella had been cut sagitally into right and left halves. Samples were processed for the following studies:

1. Light microscopic study.

2. Morphometric and Statistical Study.

\section{Light microscopic study}

The left half of the cerebellum from each animal was fixed in $10 \%$ formalin solution for one week. The specimens were processed for light microscopic study to obtain paraffin sections of $5 \mu \mathrm{m}$ thickness then stained using the following stains: -

1. Haematoxylin and eosin stain.

2. Toluidine blue stain (for demonstration of Nissl's granules).

3. Immunohistochemical stain for Glial Fibrillary Acidic Protein (GFAP) of the astrocytes.

\section{Morphometric and statistical study}

This was done using the image analyzer Leica Q win V.3 program installed on a computer in the Histology and Cell Biology Department, Faculty of Medicine, Ain Shams University. The computer was connected to a Leica 
DM2500 microscope [Wetzlar, Germany]. This image was used for calculating the following measurements:

1. The mean number of degenerated Purkinje cells/ field:

Five different stained H\&E sections from five different rats were examined in each group. From each section, five non-overlapping fields of power $[\times 40]$ were used to calculate the mean number of degenerated Purkinje cells ${ }^{[15]}$.

2. The mean number of positive (GFAP) immunostained astrocytes/field:

Five different immunostained (GFAP) sections from five different rats were examined in each group. From each section, five non-overlapping fields of power $(\times 100)$ were used to calculate the mean number of positive (GFAP) immunostained astrocytes $^{[16 \text { and } 17]}$.

\section{Statistical analysis}

All data were collected and then subjected to statistical analysis using SPSS computer program version 17.The data were presented in the form of mean \pm standard deviation (SD). Significance of difference by least significant difference (LSD) of all groups using Analysis of Variance (ANOVA) test was determined by probability of significance value ( $P$ value). Significance is considered when $p<0.05$.

\section{RESULTS}

\section{Fluid intake among different groups}

The average amount of water intake in all subgroups of the control group was $17 \mathrm{ml} / \mathrm{rat} / \mathrm{day}$. In subgroup IIA the average amount of water intake was $15 \mathrm{ml} / \mathrm{rat} /$ day. Meanwhile it was found that the average amount of Diet Coke intake in subgroup IIB was $22 \mathrm{ml} / \mathrm{rat} /$ day. The average amount of water intake was $24 \mathrm{ml} / \mathrm{rat} /$ day in group III. In subgroup IVA, the average amount of water intake was $22.5 \mathrm{ml} / \mathrm{rat} /$ day. While in subgroup IVB the average amount of Diet Coke intake was $30 \mathrm{ml} / \mathrm{rat} /$ day.

\section{Histological results}

\section{Group I (control group)}

Examination of histological sections of rats of subgroups IB and IC showed a picture that appeared similar to that of subgroup IA. H\&E stained sections of cerebellar cortex of rats of subgroup IA showed that it was formed of three successive layers. The outermost was the molecular layer; the middle was the Purkinje cell layer, while the granular layer was the innermost (Figure 1). Purkinje cells appeared flask shaped with apical dendrites. They were arranged in one row. They were characterized by pale basophilic cytoplasm and a central vesicular nuclei with prominent nucleoli. The innermost granular layer contained two types of cells; closely packed granule cells and Golgi type II cells and cerebellar islands between them (Figure 2).
In toluidine blue stained section of cerebellar cortex Purkinje cells cytoplasm appeared studded with coarse Nissl's granules surrounding the vesicular central nuclei (Figure 3).

Immunostained sections showed few GFAP positive immunoreactive astrocytes dispersed in the Purkinje cell layer and in the granular layer of the cerebellar cortex (Figure4).

\section{Group II (Diet Coke Group)}

\section{Subgroup IIA}

H\&E stained sections of cerebellar cortex of rats of subgroup IIA revealed that some Purkinje cells appeared degenerated. They were seen shrunken with distorted shape. They were surrounded by halos of empty spaces. Nuclei of cells of the granule layer appeared shrunken and deeply stained with spaces in between them (Figure 5).

Toluidine blue stained section showed Purkinje cells studded with Nissl's granules that surrounded the vesicular nuclei (Figure 6).

GFAP Immunostained cerebellar sections of group IIA showed an apparent increase in the number of GFAP positive immunoreactive astrocytes in all layers of cerebellar cortex, as compared to the control group (Figures 7A and B).

\section{Subgroup IIB}

Examination of H\&E stained sections showed that the cerebellar cortex of rats of subgroup IIB were apparently more affected as compared to subgroup IIA. Degenerated Purkinje cells were seen, with darkly stained cytoplasm and nuclei. Halos of empty spaces around degenerated Purkinje cells were also detected. The Molecular layer showed empty spaces. Cells of the granular layer showed darkly stained nuclei with spaces between them. (Figure 8).

Some Purkinje cells were lightly stained as compared to control group with apparent reduction in their Nissl's granules content in toluidine blue stained sections (Figure 9).

Immunostained sections showed an apparent increase in the number of GFAP positive immunoreactive in all layers of the cortex, as compared to the control group (Figure10).

\section{Group III (Monosodium Glutamate group)}

The cerebellar cortex sections of this group showed apparent more degenerative change as compared to that of group II.

Examination of H\&E stained sections showed that some distorted Purkinje cells appeared with pale cytoplasm and ill-defined nuclei, while others were seen with dark cytoplasm and nuclei. Halos of empty spaces around the degenerated Purkinje cells could be detected. Cells of granular layer appeared with darkly stained nuclei with 
empty spaces between these cells (Figure 11).

In toluidine blue stained section some Purkinje cells had apparently less Nissl's granules, so cytoplasm became pale as compared to control group, while others appeared shrunken and deeply stained (Figure 12).

An apparent increase in the number of GFAP positively stained astrocytes in all layers of the cortex, as compared to control group and group II, in immunostained sections was detected (Figure 13).

\section{Group IV (Combination group)}

\section{Subgroup IVA}

Examination of H\&E stained sections showed Purkinje cells with dark stained cytoplasm and dark pyknotic eccentric nuclei. Nuclei of some Purkinje cells couldn't be seen. Halo of empty spaces around shrunken Purkinje cells were noticed. Empty spaces in molecular and granular layers could be also detected (Figure 14).

In toluidine blue stained section of cerebellar cortex, the cytoplasm of distorted Purkinje showed apparently less Nissl's granules than control group, subgroup IIA, subgroup IIB and group III (Figure 15).

Immunostained sections of cerebellar cortex of subgroup IVA showed an apparent increase in the number of GFAP positively stained in all layers of the cortex, as compared to the control group, both subgroups of group II and group III (Figure 16).

\section{Subgroup IVB}

Examination of H\&E stained sections of cerebellar cortex revealed that some Purkinje cells showed dark stained nuclei and vacuolations in the darkly stained cytoplasm. Halos of empty spaces around degenerated Purkinje cells and empty areas of lost Purkinje cells could be detected. Empty spaces in the molecular and the granular layers could be noticed (Figure 17).

In toluidine blue stained section, the cytoplasm of shrunken Purkinje cells showed an apparent reduction of Nissl's granules content compared to control, subgroup IIA, subgroup IIB and group III. (Figure 18).

Immunostained sections, showed an apparent increase in the number of GFAP positive immunoreactive in all layers of the cerebellar cortex, compared to all other groups and subgroups. The astrocytes showed long interdigitating processes (Figure 19).

\section{Morphometric and statistical results}

\section{I- Mean weight in grams in different groups}

At the end of the experiment, there was a nonsignificant increase in the mean weight of subgroup IIA when compared to group I. There was a significant increase in the mean weight in subgroup IIB as compared with subgroup IIA and group I. In addition, there was significant increase in the mean weight in group III when compared with group I, subgroup IIA and subgroup IIB. There was significant increase in the mean weight in subgroup IVA when compared with group I, subgroup IIA, subgroup IIB and group III. Subgroup IVB showed significant increase in the mean weight when compared to all other studied groups and subgroups (Table 1, Histogram 1).

II- Mean number of degenerated Purkinje cells/field in $H \& E$ stained cerebellar sections at $x 40$ magnification in different groups

There was non-significant change in the mean number of degenerated Purkinje cells of cerebellar cortex of rats of subgroup IIA as compared to group I. On the other hand, there was significant increase in the mean number of degenerated Purkinje cells of cerebellar cortex of rats of subgroup IIB, group III and both subgroups of group IV when compared with group I (control group). Similarly, there was a significant increase in the mean number of degenerated Purkinje cells in subgroup IIB as compared with subgroup IIA.

In addition, there was significant increase in the mean number of degenerated Purkinje cells in group III when compared to both subgroups of group II. In addition, there was significant increase in the mean number of degenerated Purkinje cells in subgroup IVA when compared with both subgroups of group II and group III. Also, significant increase in the mean number of degenerated Purkinje cells was present in subgroup IVB when compared to all other studied groups and subgroups (Table 2, Histogram 2).

III- Mean number of positive GFAP immunostained astrocytes/field counted at $x 100$ magnification in different groups

There was a significant increase in the mean number of positive immunostained astrocytes of all groups and subgroups when compared with group I (control group). Similarly, there was a significant increase in the mean number of positive immunostained astrocytes in subgroup IIB as compared with subgroup IIA.

In addition, there was significant increase in the mean number of positive immunostained astrocytes in group III when compared with both subgroups of group II. Also, significant increase in the mean number of positive immunostained astrocytes was present in subgroup IVA when compared with subgroup IIA, subgroup IIB and group III. There was a significant increase in the mean number of positive immunostained astrocytes cells in subgroup IVB when compared to both subgroups of group II, group III and subgroup IVA. (Table 3, Histogram 3) 


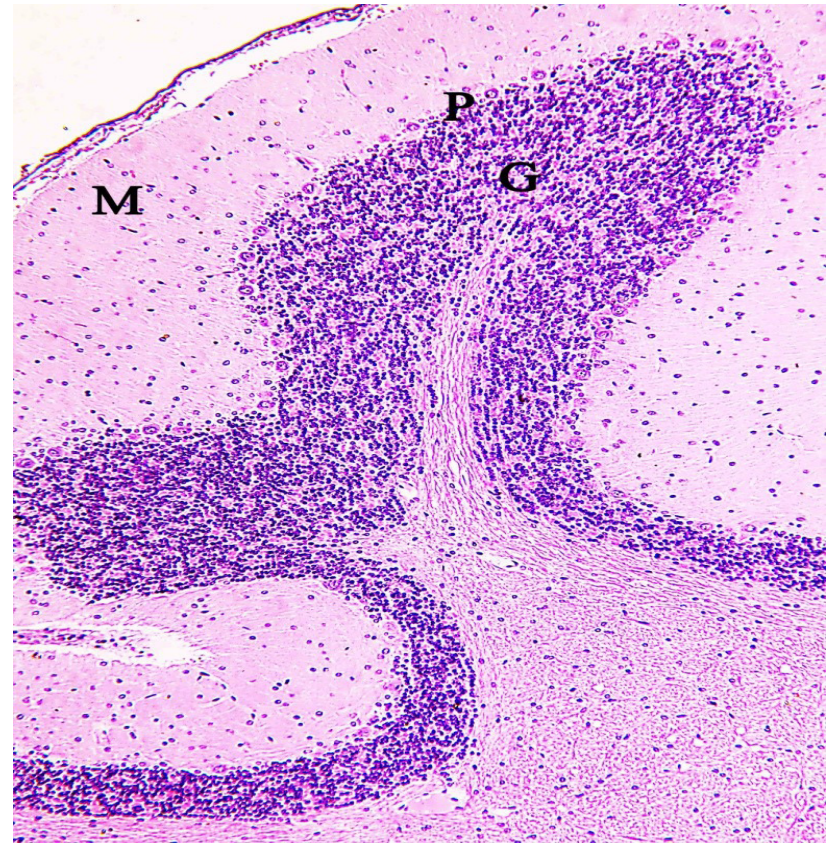

Fig. 1: A photomicrograph of a section of a rat cerebellar cortex showing its three layers; outer molecular $(\mathrm{M})$, middle Purkinje $(\mathrm{P})$ and inner granular (G) layers. (Group I, H\&E x 100)

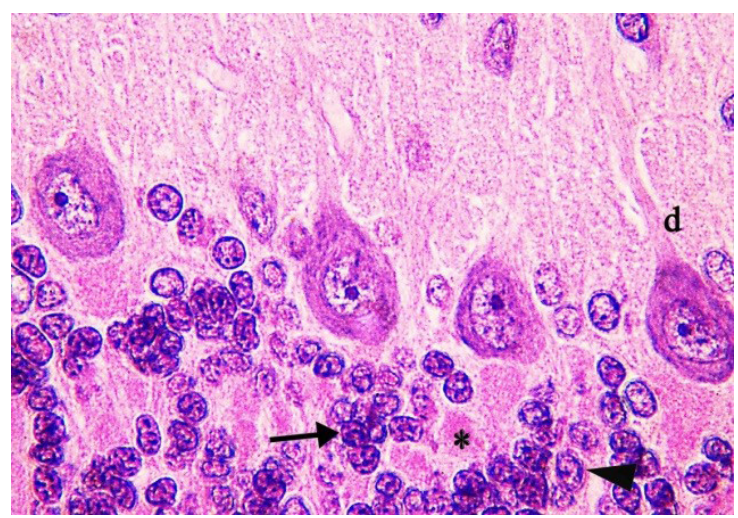

Fig. 2: A photomicrograph of a section a rat cerebellar cortex showing one row of flask shaped Purkinje cells, with apical dendrites (d). Granular layer contains small closely packed granule cells $(\uparrow)$ and Golgi type II cells $(\mathbf{\Lambda})$. Cerebellar islands $\left(^{*}\right)$ can be seen between these cells. (Group I, H\&E x 1000)

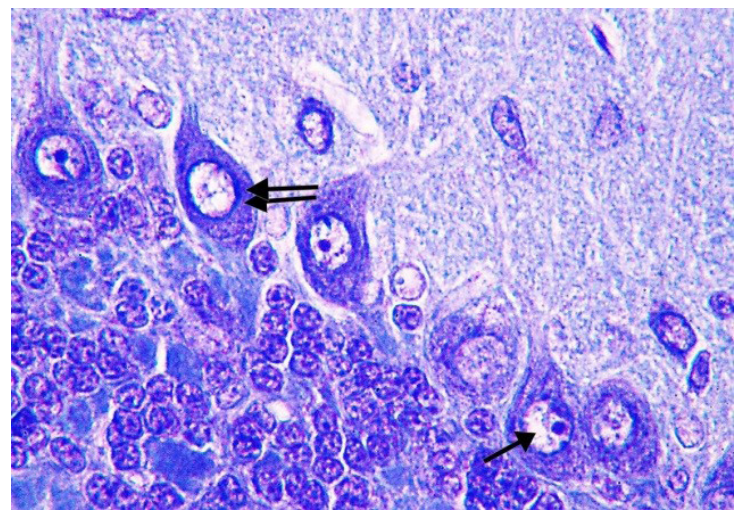

Fig. 3: A photomicrograph of a section of adult male albino rat cerebellar cortex showing Purkinje cells with vesicular centrally located nuclei ( $\uparrow)$ surrounded by Nissl's granules ( $\uparrow$ ). (Group I, TB x 1000)

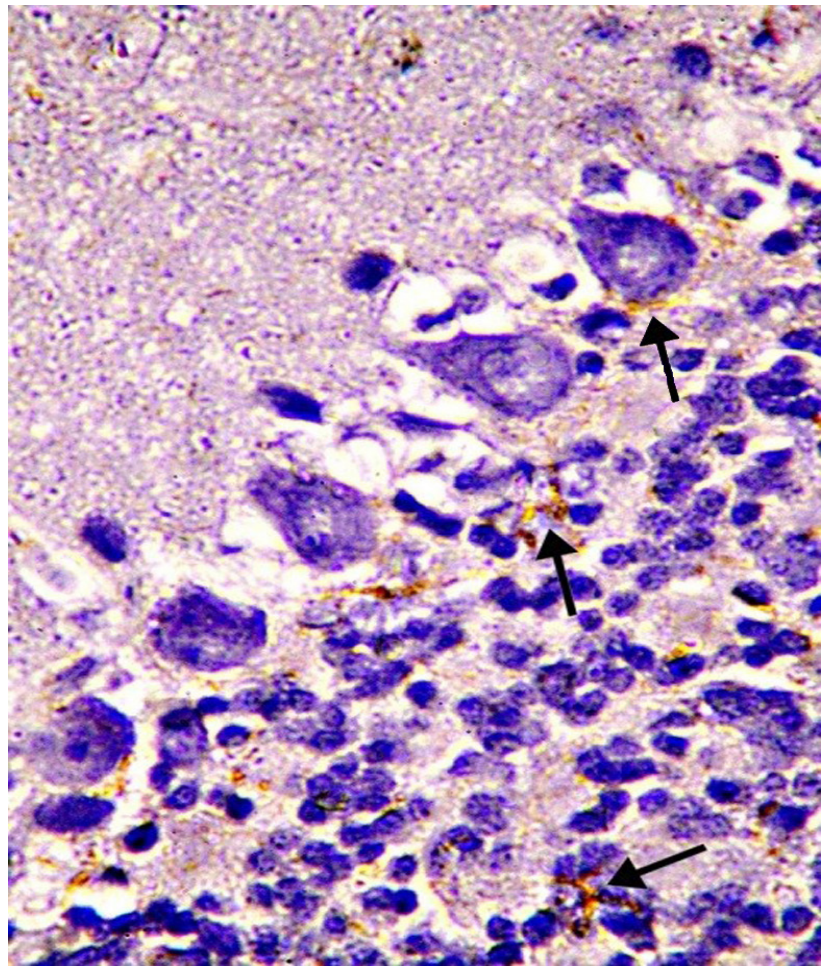

Fig. 4: A photomicrograph of a section a rat cerebellar cortex showing few GFAP immunoreactive astrocytes scattered in the Purkinje cell layer and in the granular layer $(\uparrow)$. (Group I, GFAP x 1000)

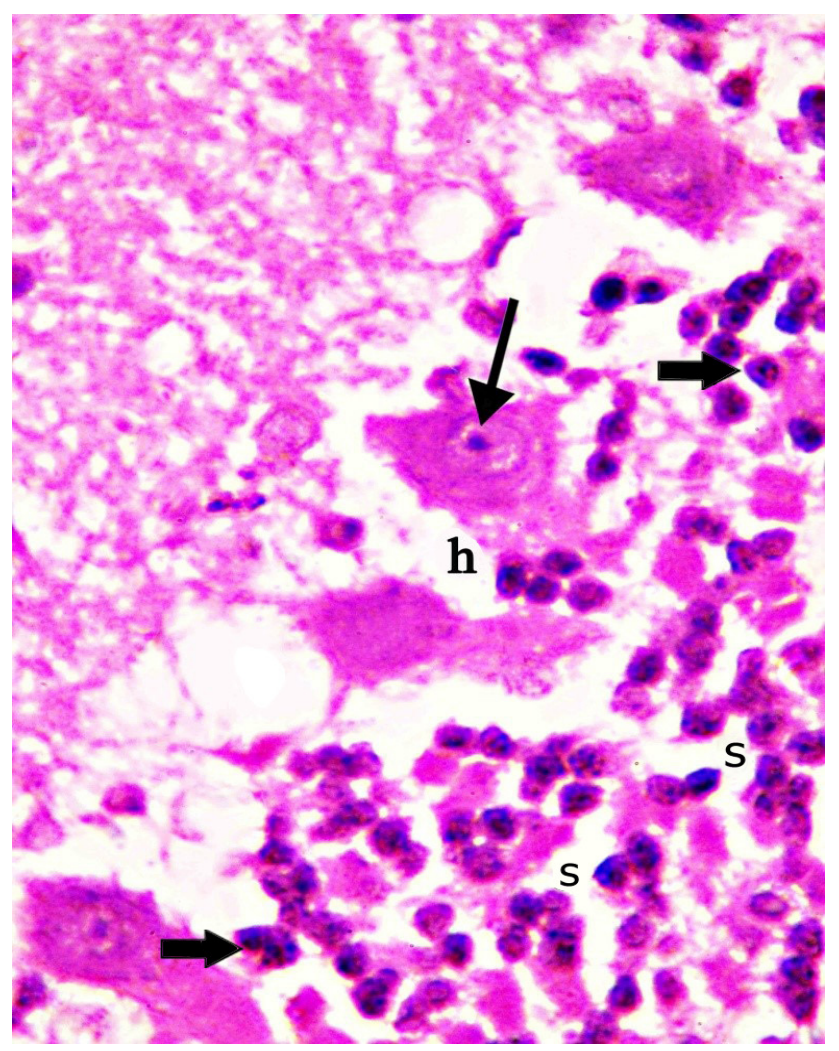

Fig. 5: A photomicrograph of a section of a rat cerebellar cortex showing shrunken Purkinje cell with halo of empty space (h) around it. Notice some Purkinje cells appear with vesicular nuclei $(\uparrow)$. Cells of Nuclei of the granule layer appear with shrunken and deeply stained nuclei (1-). Spaces in between them are seen (S). (Subgroup IIA, H\&E x1000) 


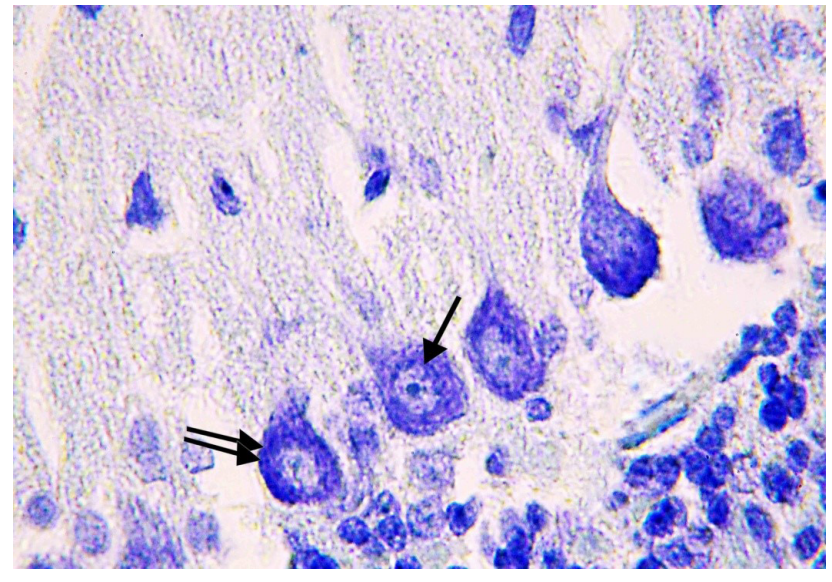

Fig. 6: A photomicrograph of a section of a rat cerebellar cortex showing Purkinje cells with Nissl's granules $(\uparrow \uparrow)$ in their cytoplasm surrounding the centrally located nuclei $(\uparrow) . \quad$ (subgroup IIA, TB x 1000)
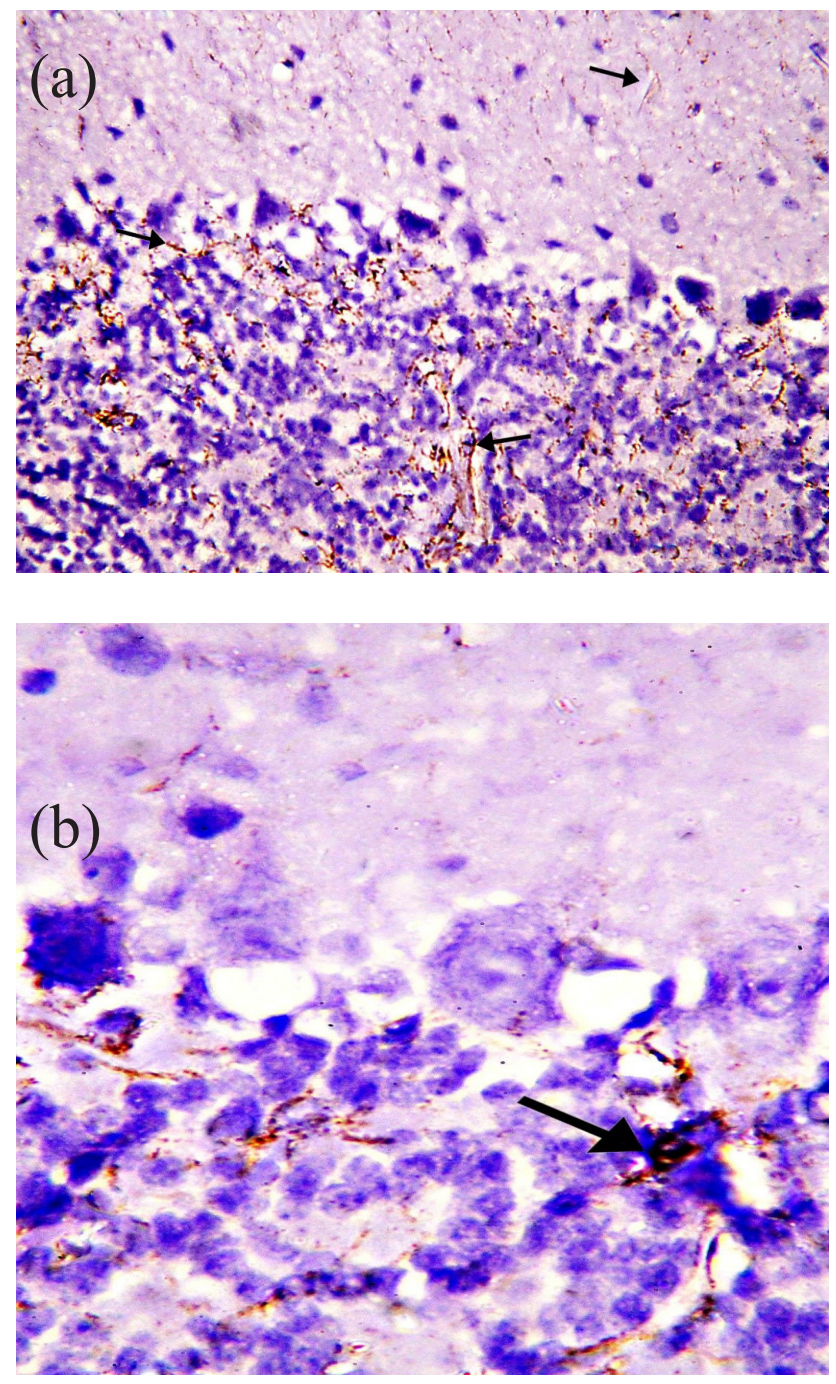

Fig. 7: (a) A photomicrograph of a section of a rat cerebellar cortex showing GFAP positive immunoreactive astrocytes in all layers of the cortex $(\uparrow)$. (b) Showing GFAP immunostained astrocyte in the granular layer $(\uparrow)$.

(Subgroup IIA, GFAP (a) x 400, (b) x1000)

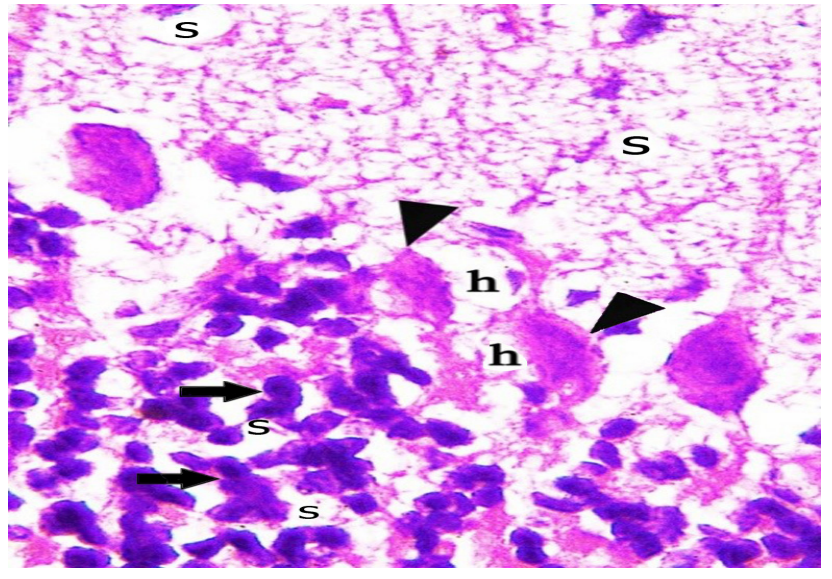

Fig. 8: A photomicrograph of a section of a rat cerebellar cortex showing some degenerated Purkinje cells $(\boldsymbol{\Delta})$ with halos of empty spaces (h) around them. Molecular and granular layers shows some spaces (s). Notice nuclei of cells of granular layer appear darkly stained (个) (Subgroup IIB, H\&E x 1000

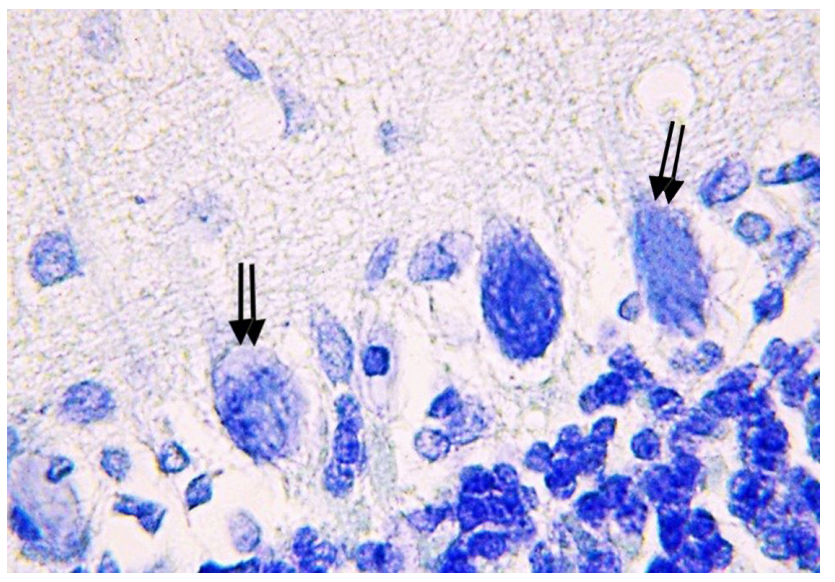

Fig. 9: A photomicrograph of a section of a rat cerebellar cortex showing some Purkinje cells with apparent reduction in their Nissl's granules $(\uparrow \uparrow)$ giving the cytoplasm faint appearance. (Subgroup IIB, TB x 1000)

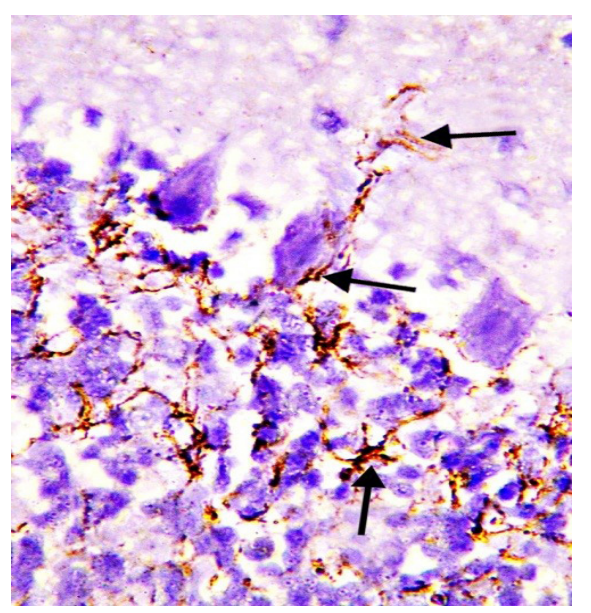

Fig. 10: A photomicrograph of a section of a rat cerebellar cortex showing many GFAP positive immunoreactive astrocytes in all layers of the cortex $(\uparrow)$. (Subgroup IIB, GFAP x 1000) 


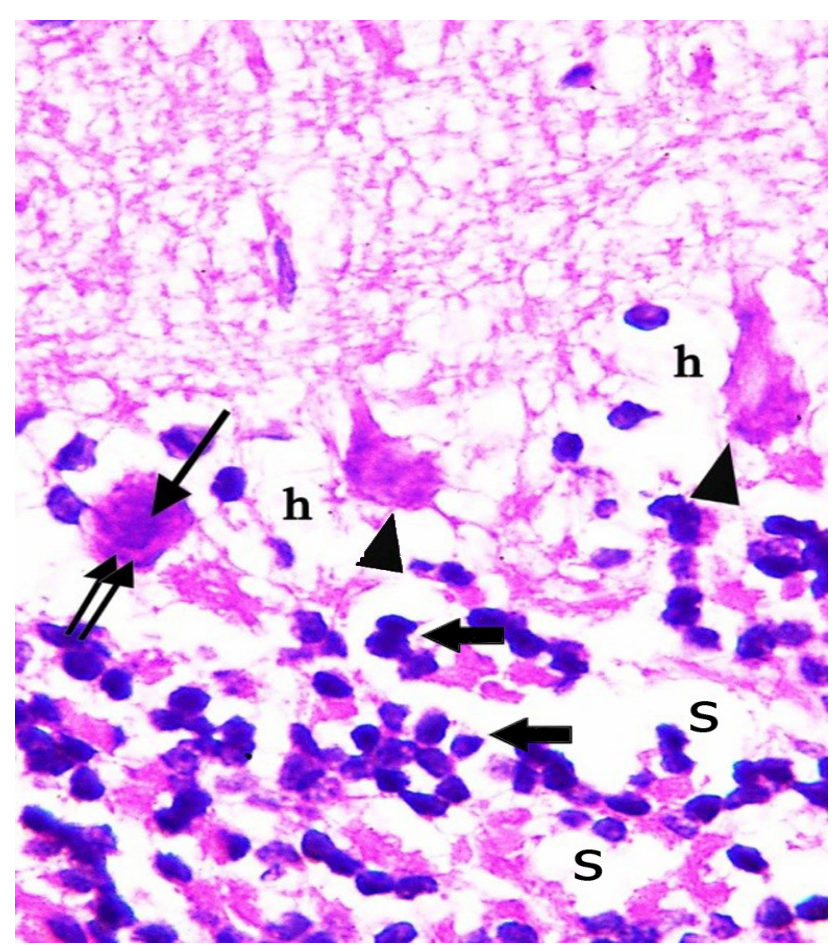

Fig. 11: A photomicrograph of a section of a rat cerebellar cortex. Some Purkinje cells appear distorted with pale cytoplasm and ill-defined nuclei $(\boldsymbol{\Delta})$.Others show dark cytoplasm $(\uparrow \uparrow)$ and dark nuclei $(\uparrow)$. Halos of empty spaces (h) around Purkinje cells can be seen. Cells of granular layer show dark nuclei (1) with empty spaces in between (S). (Group III, H\&E $\mathrm{x} 1000)$

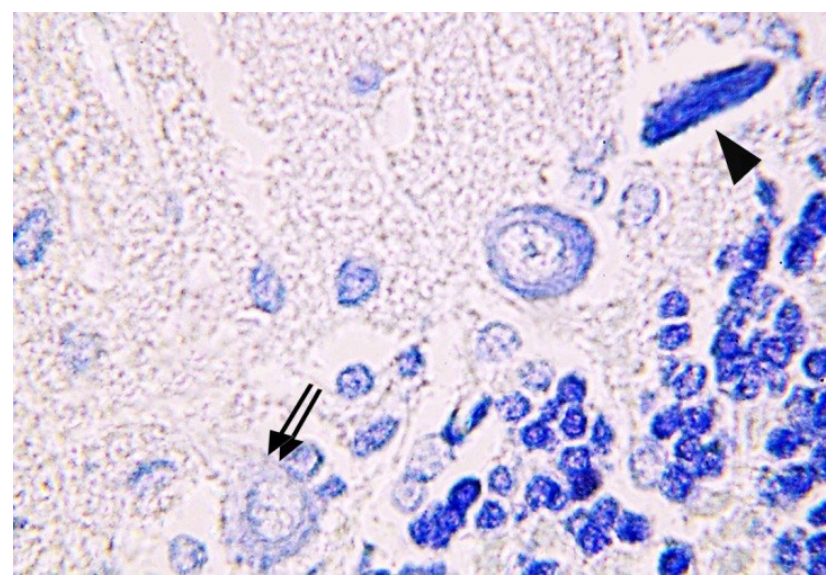

Fig. 12: A photomicrograph of a section of a rat cerebellar cortex. The cytoplasm of some Purkinje cells appears pale with apparently few Nissl's granules $(\uparrow \uparrow)$, others appear shrunken and deeply stained $(\boldsymbol{\Delta})$.

(Group III, TB x1000)

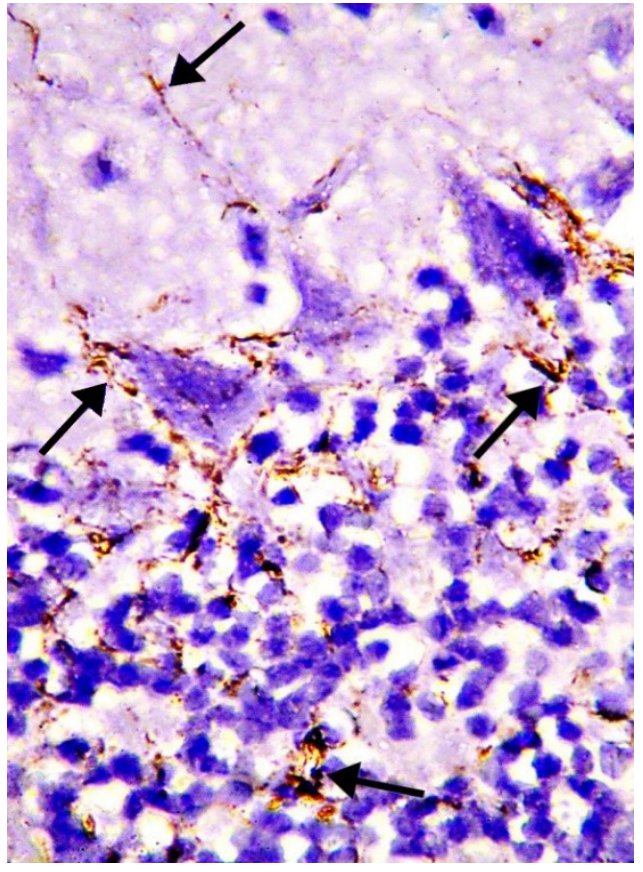

Fig. 13: A photomicrograph of a section of a rat cerebellar cortex showing an apparent numerous GFAP positively stained astrocytes in all layers of the cortex $(\uparrow)$. (Group III, GFAP x 1000)

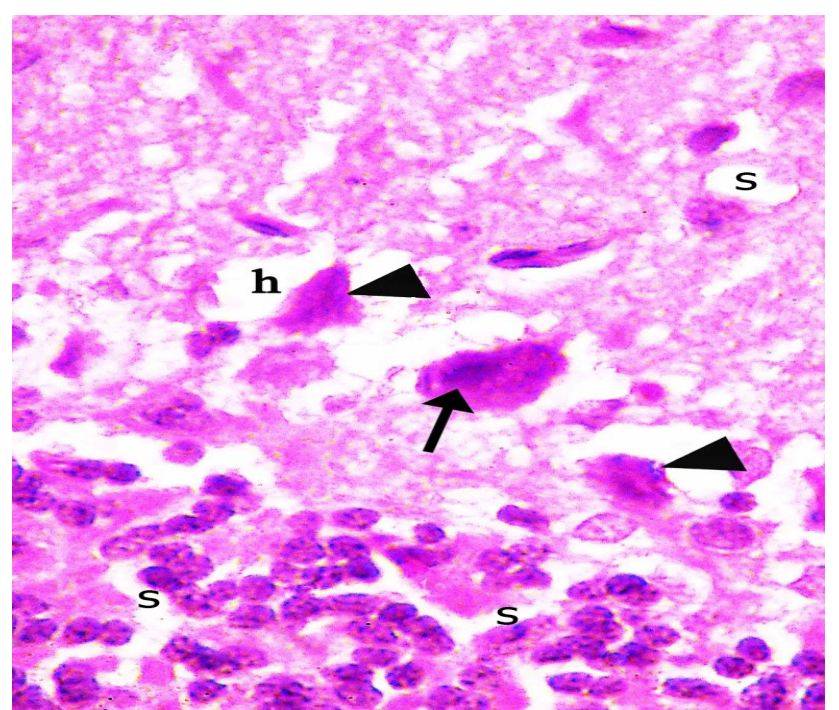

Fig. 14: A photomicrograph of a section of a rat cerebellar cortex showing shrunken Purkinje cells with dark stained cytoplasm $(\boldsymbol{\Delta})$. Notice the pyknotic eccentric nucleus of Purkinje cell $(\uparrow)$. Halos of empty space (h) around degenerated Purkinje cells can be detected. Empty spaces (s) in molecular and the granular layers are seen. $\mathrm{H} \& \mathrm{E} \times 1000)$

(Subgroup IVA, 


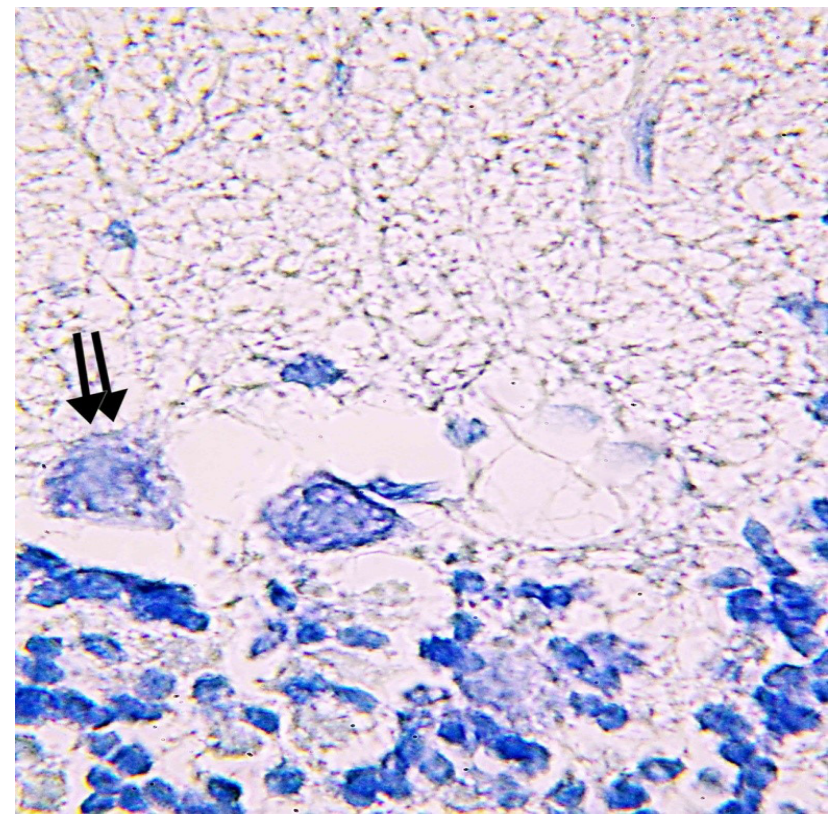

Fig. 15: A photomicrograph of a section of a rat cerebellar cortex. Distorted Purkinje cells showing dissolution of its Nissl's granules with apparently pale cytoplasm ( $\uparrow)$. (Subgroup IVA, TB x1000)

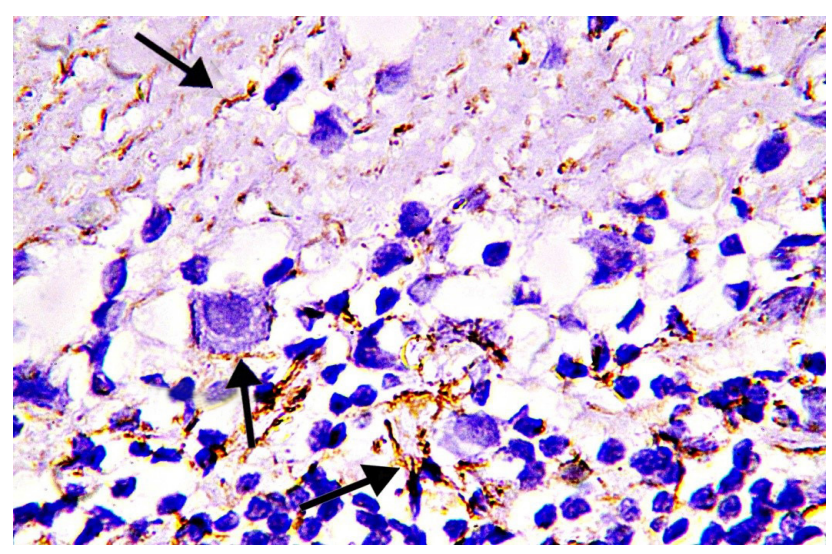

Fig. 16: A photomicrograph of a section of a rat cerebellar cortex showing many GFAP positive immunostained astrocytes in all layers of cortex $(\uparrow)$ (Subgroup IVA, GFAP x1000)

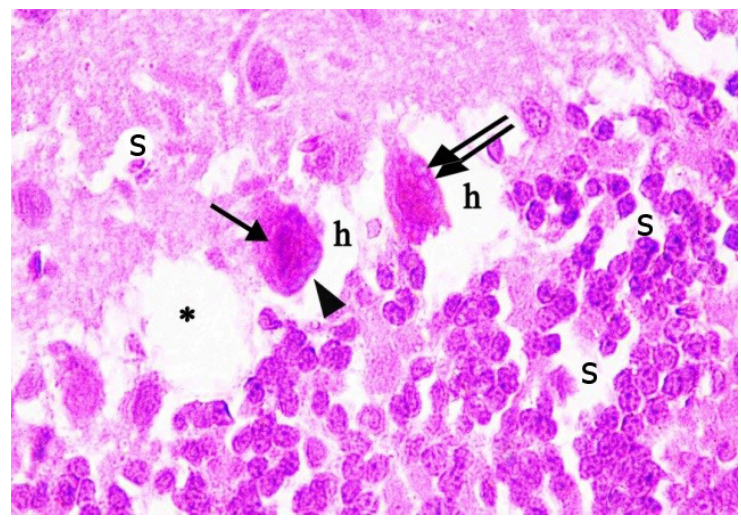

Fig. 17: A photomicrograph of a section of a rat cerebellar cortex showing shrunken Purkinje cell with dark stained cytoplasm $(\boldsymbol{\Delta})$ and nucleus $(\uparrow)$. Vacuolation in the cytoplasm of Purkinje cell $(\uparrow \uparrow)$ is detected. Halos of empty spaces (h) are seen around degenerated Purkinje cells. Empty area of lost Purkinje cells $\left(^{*}\right)$ can be seen. Notice spaces (s) in the molecular and granular layers. (Subgroup IVB, H\&E x1000)

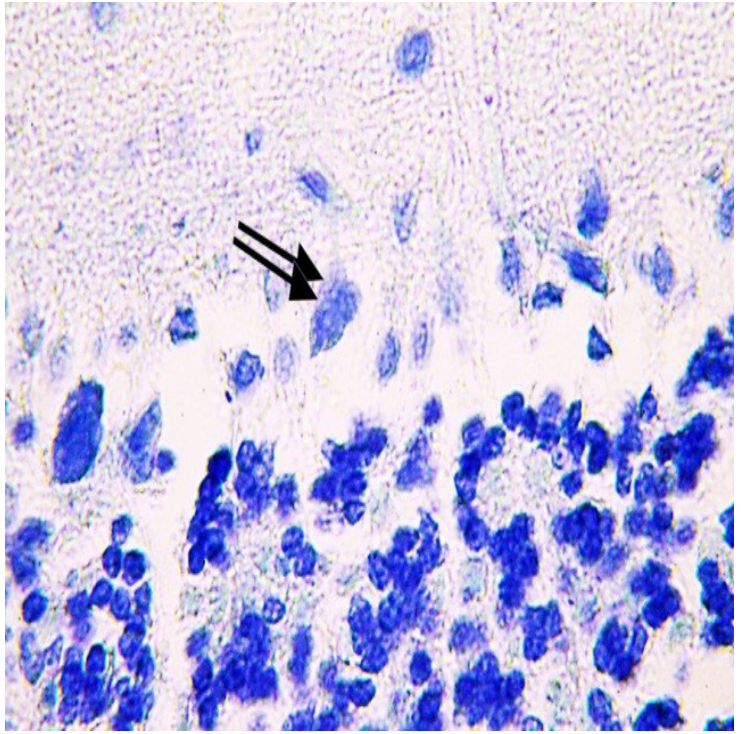

Fig. 18: A photomicrograph of a section of a rat cerebellar cortex. The cytoplasm of distorted Purkinje cell shows few Nissl's granules $(\uparrow \uparrow)$ (Subgroup IVB, TB x1000)

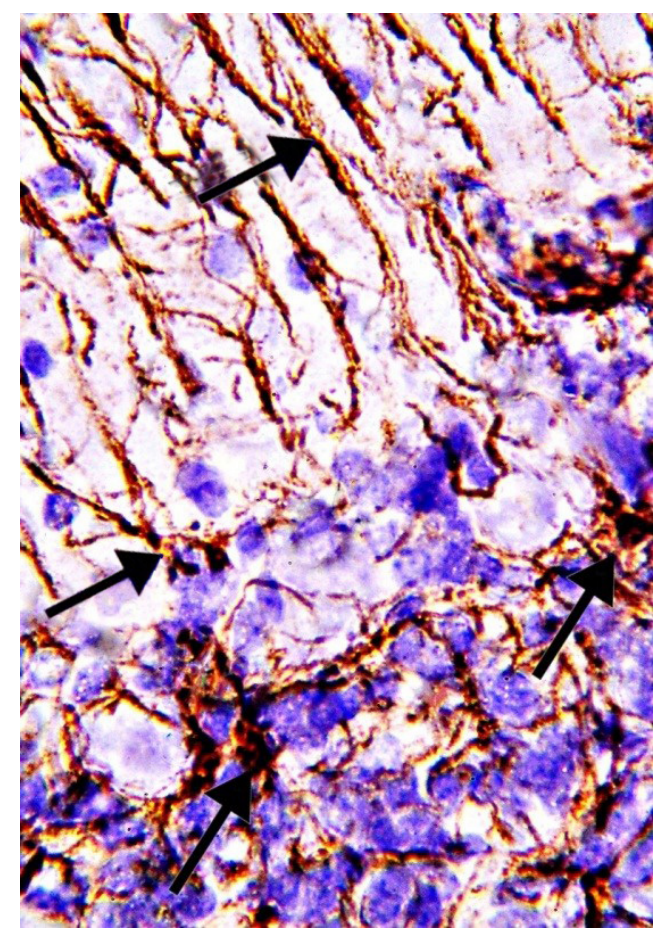

Fig. 19: A photomicrograph of a section of a rat cerebellar cortex showing numerous GFAP positively stained astrocytes in all layers of the cortex $(\uparrow)$. Notice the long interdigitating processes of astrocytes. (Subgroup IVB, GFAP x 1000) 
Table 1: Mean weight in grams in different groups

\begin{tabular}{|c|c|c|c|c|c|c|}
\hline $\begin{array}{l}\text { The mean weight } \\
\text { in grams } \pm \mathrm{SD}\end{array}$ & Group I Mean \pm SD & \multicolumn{2}{|c|}{ Group II } & Group III mean \pm SD & \multicolumn{2}{|c|}{ Group IV } \\
\hline Initial weight & $201.4 \pm 5.813$ & $\begin{array}{c}\text { Subgroup IIA } \\
\text { mean } \pm \text { SD }\end{array}$ & $\begin{array}{c}\text { Subgroup IIB } \\
\text { mean } \pm \text { SD }\end{array}$ & $200 \pm 24.382$ & $\begin{array}{c}\text { Subgroup IVA } \\
\text { mean } \pm \mathrm{SD}\end{array}$ & $\begin{array}{c}\text { Subgroup IVB } \\
\text { mean } \pm \text { SD }\end{array}$ \\
\hline & & $204.6 \pm 8.080$ & $198.8 \pm 5.71$ & & $203.4 \pm 10.212$ & $202.6 \pm 3.974$ \\
\hline End of the study & $206.6+6.795$ & $213+7.648$ & $237.2+12.93^{=\star}$ & $256.2+21.229=0$ & $263+8.455^{\sim ↔ 0 \Delta}$ & $284.2+5.718 \leadsto$ \\
\hline
\end{tabular}

- Significance of difference by LSD of all groups and subgroups from control group at least $P>0.05$

- Significance of difference by LSD of all groups and subgroups from subgroup IIA at least $P>0.05$

O Significance of difference by LSD of all groups and subgroups from subgroup IIB at least $P>0.05$

$\boldsymbol{\Delta}$ Significance of difference by LSD of all groups and subgroups from group III at least $P>0.05$

* Significance of difference by LSD of all groups and subgroups from subgroup IVA at least $P>0.05$

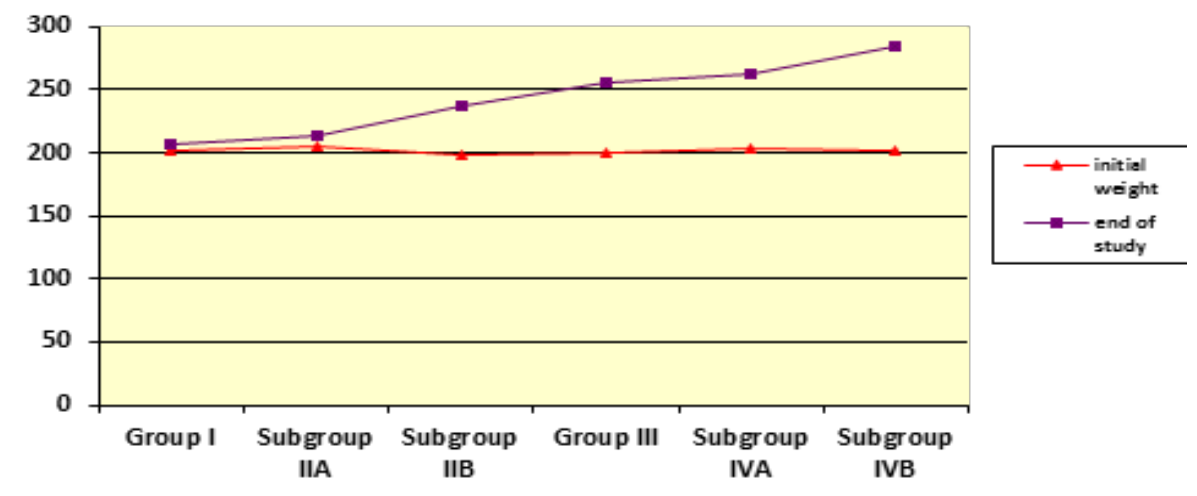

Histogram 1: The mean weight in grams in different groups

Table 2: The mean number of degenerated Purkinje cells/field in different groups

\begin{tabular}{|c|c|c|c|c|c|c|}
\hline \multirow{3}{*}{$\begin{array}{l}\text { The mean number } \\
\text { of degenerated } \\
\text { Purkinje cells } \\
\quad \pm \text { S.D }\end{array}$} & $\begin{array}{c}\text { Group I } \\
\text { mean } \pm \text { SD }\end{array}$ & \multicolumn{2}{|c|}{ Group II } & Group III mean \pm SD & \multicolumn{2}{|c|}{ Group IV } \\
\hline & $1 \pm 0.02$ & $\begin{array}{c}\text { Subgroup IIA } \\
\text { mean } \pm \text { SD }\end{array}$ & $\begin{array}{c}\text { Subgroup IIB } \\
\text { mean } \pm \text { SD }\end{array}$ & $3.8 \pm 0.836^{\text {= }}$ & $\begin{array}{c}\text { Subgroup IVA } \\
\text { mean } \pm \text { SD }\end{array}$ & $\begin{array}{c}\text { Subgroup IVB } \\
\text { mean } \pm \mathrm{SD}\end{array}$ \\
\hline & & $1.4 \pm 0.894$ & $2.6 \pm 0.547^{m b}$ & & $5 \pm 1=0$ ॥ & $6.60 \pm 0.894=$ \\
\hline
\end{tabular}

- Significance of difference by LSD of all groups and subgroups from control group at least $P>0.05$

- Significance of difference by LSD of all groups and subgroups from subgroup IIA at least $P>0.05$

O Significance of difference by LSD of all groups and subgroups from subgroup IIB at least $P>0.05$

$\Delta$ Significance of difference by LSD of all groups and subgroups from group III at least $P>0.05$

* Significance of difference by LSD of all groups and subgroups from subgroup IVA at least $P>0.05$

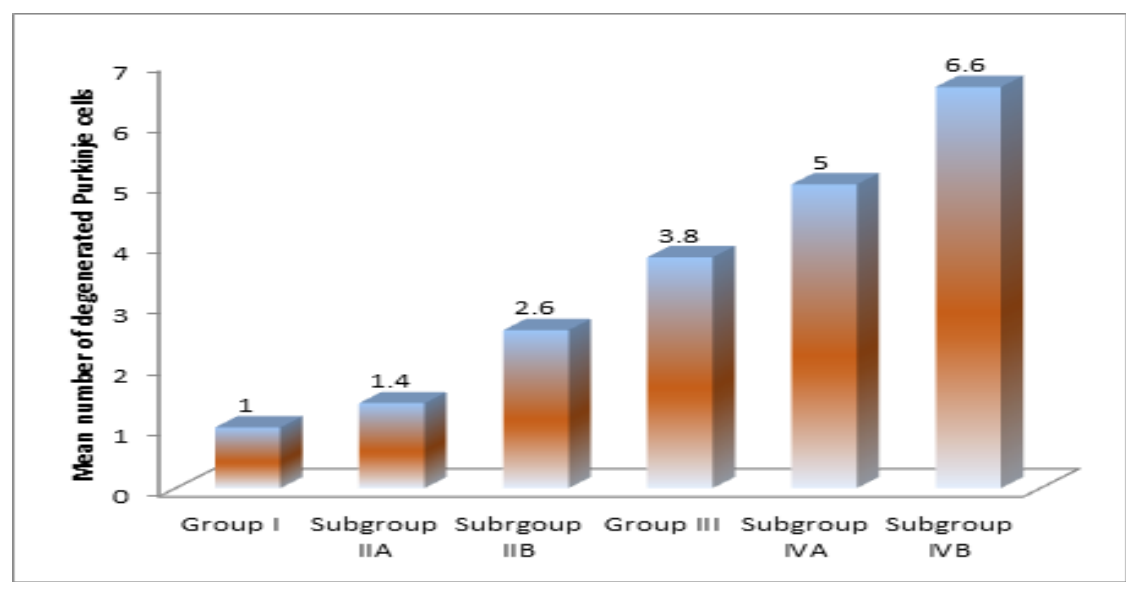

Histogram 2: The mean number of degenerated Purkinje cells/field in different groups. 
Table 3: The mean number of positive GFAP immunostained astrocytes cells/field in different groups

\begin{tabular}{|c|c|c|c|c|c|c|}
\hline \multirow{3}{*}{$\begin{array}{l}\text { The mean number } \\
\text { of positive } \\
\text { immunostained } \\
\text { astrocytes / } \\
\text { field } \pm \text { S.D }\end{array}$} & \multirow{2}{*}{$\begin{array}{c}\begin{array}{c}\text { Group I } \\
\text { mean } \pm \text { SD }\end{array} \\
1.392 \pm 0.011\end{array}$} & \multicolumn{2}{|c|}{ Group II } & \multirow{2}{*}{$\begin{array}{c}\text { Group III mean } \pm \text { SD } \\
7.673 \pm 0.030 \text { «0 }\end{array}$} & \multicolumn{2}{|c|}{ Group IV } \\
\hline & & $\begin{array}{c}\text { Subgroup IIA } \\
\text { mean } \pm \text { SD }\end{array}$ & $\begin{array}{c}\text { Subgroup IIB } \\
\text { mean } \pm \text { SD }\end{array}$ & & $\begin{array}{c}\text { Subgroup IVA } \\
\text { mean } \pm \mathrm{SD}\end{array}$ & $\begin{array}{c}\text { Subgroup IVB } \\
\text { mean } \pm \text { SD }\end{array}$ \\
\hline & & $4.462 \pm 0.039$ & $5.675 \pm 0.007 *$ & & $8.928 \pm 0.026^{= \pm 0 \Delta}$ & $10.782 \pm 0.037=$ \\
\hline
\end{tabular}

- Significance of difference by LSD of all groups and subgroups from control group at least $P>0.05$

- Significance of difference by LSD of all groups and subgroups from subgroup IIA at least $P>0.05$

O Significance of difference by LSD of all groups and subgroups from subgroup IIB at least $P>0.05$

$\Delta$ Significance of difference by LSD of all groups and subgroups from group III at least $P>0.05$

* Significance of difference by LSD of all groups and subgroups from subgroup IVA at least $P>0.05$

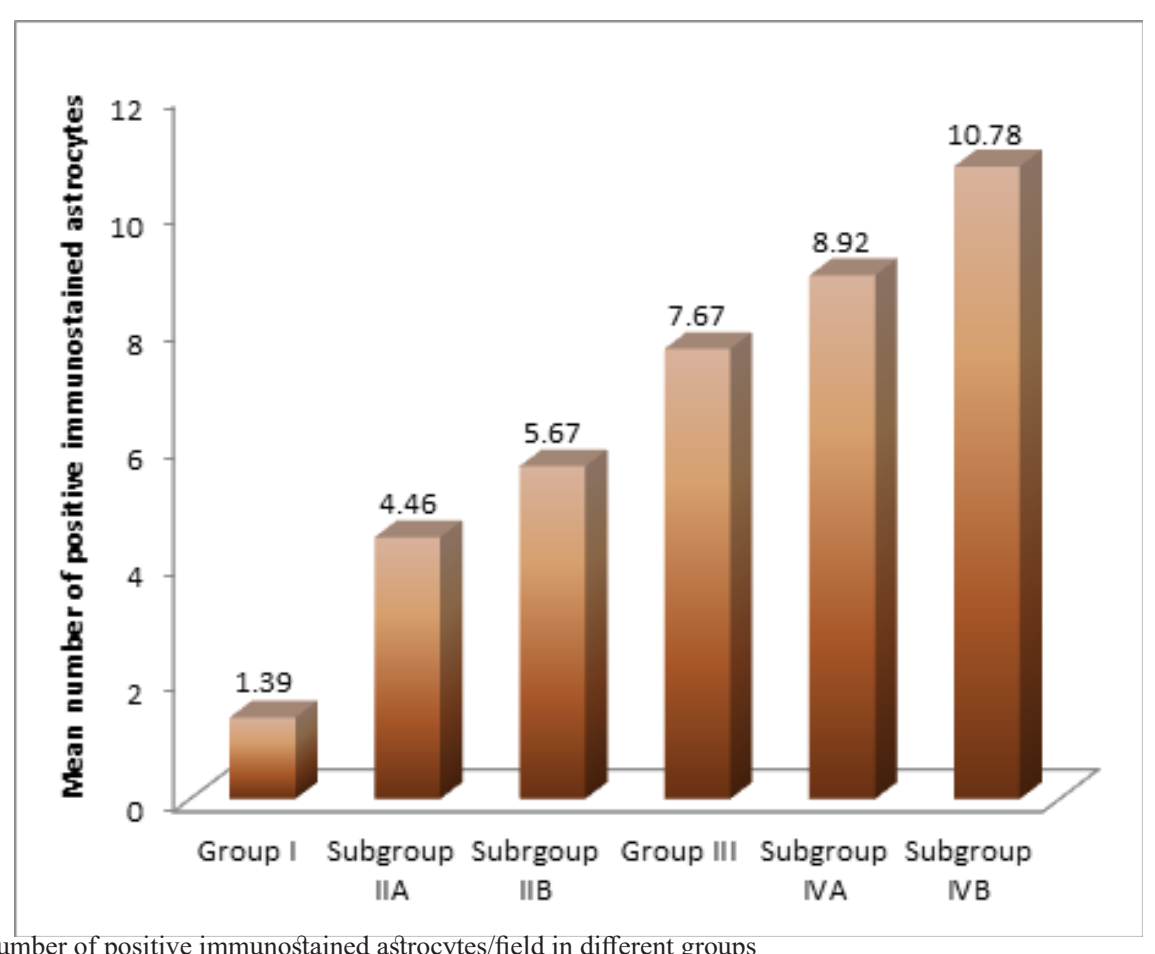

Histogram 3: The mean number of positive immunostained astrocytes/field in different groups

\section{DISCUSSION}

Fast food with non-caloric beverage, mostly diet carbonated drinks are used by some people to decrease the weight gain so, this study was carried out to detect the effect of diet carbonated drink and MSG either separately or in combination on the cerebellar cortex of adult male albino rats with assessment of the weight gain at the end of the study.

In the present study, the statistical results revealed at the end of the study, there was a significant increase in the mean weight in subgroup IIB as compared with subgroup IIA and group I.

Eweis et al., 2107 $7^{[18]}$ observed elevated level of the hunger hormone ghrelin and thus greater food intake in rats drinking diet carbonated drinks. They mentioned that elevated level of ghrelin might be a consequence of the lack of sugar in diet drinks which probably induce rats to crave food to balance the non-nutritive aspect of diet drinks. They concluded that the lack of sugar or calories in carbonated drinks still leads to increased food consumption and weight gain.
On the contrary, Abu-Taweel et al., $2104^{[19]}$ found that rats administrated aspartame at a dose of $32 \mathrm{mg} / \mathrm{kgm}$ body weight/day for 30 days had significant depletion in their body weight gain compared to their respective control group.

The present study showed that there was significant increase in the mean weight in group III when compared with group I, subgroup IIA and subgroup IIB.

In agreement with these result, Alao et al., 2010 ${ }^{[10]}$ found increase weight of Wistar rats treated with $2 \mathrm{ml}$ and $1 \mathrm{ml}$ of $0.5 \mathrm{gm} / \mathrm{ml} /$ rat MSG solution per day for 14 and 28 days respectively.

Moreover, Balbo et al., 2000 ${ }^{[20]}$ and Miranda et al., $2014^{[21]}$ reported that $4 \mathrm{mg} \mathrm{MSG} / \mathrm{g}$ body weight injected subcutaneously for 5 days induced obesity in neonatal male rats.

Khalaf and Arafat, 2015 [22] mentioned that MSG is considered as a leading cause of weight gain as it motivate the oro-sensory receptors, improves the deliciousness of meals and increases the appetite. 
Contini et al., 2017[23] observed sodium and water retention in rats fed a diet supplemented with $3 \mathrm{gm}$ of MSG/ $\mathrm{kgm}$ body weight/day, five days a week for 16 weeks. This might be one of the causes of increase weight gain and increase water intake in MSG treated rats in the current study as compared to control group.

On the contrary, Abu-Taweel et al., 2014 $4^{[19]}$ observed significant depletion in the body weight of rats treated with MSG at a dose of $8 \mathrm{mg} / \mathrm{kgm}$ body weight/day, for one month.

In the present study, the morphometric and statistical results revealed that at the end of the study, there was significant increase in the mean weight in subgroup IVA when compared with group I, both subgroups of group II and group III. In addition subgroup IVB showed significant increase in the mean weight when compared to group I, both subgroups of group II, group III and subgroup IVA. This might be due to the combined effect of MSG and Diet Coke.

On the contrary, Abu-Taweel et al., 2014 ${ }^{[19]}$ observed significant depletion in the body weight of rats treated with both MSG at a dose of $8 \mathrm{mg} / \mathrm{kgm}$ body weight/day and aspartame at a dose of $32 \mathrm{mg} / \mathrm{kgm}$ body weight/day, for one month.

The differences in the weight results might be due to the variations in dose regimen and perhaps to different duration of administration of Diet Coke with all its constituents not only aspartame and to amount of total fluid intake.

Alkhedaide et al., 2016 ${ }^{[24]}$ mentioned that caffeine in carbonated beverages is added to make individuals addicted and is readily absorbed rapidly compared with any other drink. This might explain the increase in average Diet Coke intake in rats of group II and group IV as compared to the average water intake of control rats in the present study.

Moreover, Goje et al., 2014 $4^{[25]}$ noted increase in the fasting blood glucose level after Coca Cola intake and stated that it might be attributed to the presence of caramel which is a major ingredient in Coca Cola soft drinks, thus Coca Cola is considered as a predisposing factor for diabetes mellitus. This might explain the increased average amount of total fluid intake in the present study.

In addition, the present study revealed that the total average amount of fluid intake either water or Diet Coke intake were increased in groups that received MSG either when administrated alone in rats of group III or in combination with Diet Coke in rats of group IV as compared to that of the control group. This increase in fluid intake accompanying MSG administration in the present study might be explained according to Kazmi et al., 2017 $7^{[26]}$ who mentioned that MSG induced diabetic condition in mice which was similar to human type II diabetes mellitus. The maximum total average fluid intake in the present study was noticed in rats of subgroup IVB followed by rats of subgroup IVA. This might be explained to be due to the combined and synergistic effect of both $\mathrm{MSG}^{[26]}$ and Diet Coke on blood glucose level ${ }^{[25]}$.

In the present work, light microscopic examination of cerebellar cortex showed that Purkinje cells were affected by Diet Coke administration. There was significant increase in the mean number of degenerated Purkinje cells of cerebellar cortex of rats of subgroup IIB as compared to control group.

The findings in the current study were coinciding with Eluwa et al., 2013 ${ }^{[13]}$ in studying the effect of diet carbonated drinks, on the histology of the cerebellum of adult female albino Wistar rats.

Abd El-Samad, 2010 ${ }^{[27]}$ found that cerebellar sections of rats received aspartame (which is the sweetener used in the Diet Coke) daily by dose of $250 \mathrm{mg} / \mathrm{kgm}$ for 8 weeks revealed similar findings.

These findings were in accordance to Mohamed, $2013^{[17]}$ who found that, Purkinje cells in cerebellar sections of animals that received aspartame at a dose of $20 \mathrm{mg} /$ day for 6 months appeared shrunken with deeply stained cytoplasm and ill-defined nuclei with apparent decrease in the number of Purkinje cells.

Similarly, Abdul-Hamid and Gallaly, 2014 ${ }^{[28]}$ observed that cerebellar sections of animals that received $250 \mathrm{mg}$ / $\mathrm{kgm} /$ body weight aspartame daily for 2 months revealed deeply stained Purkinje cells.

Humphries et al., 2008 ${ }^{[29]}$ explained that aspartic acid is an excitatory neurotransmitter. It resultes from hydrolysis of aspartame in intestine and could cross the blood brain barrier by competition on the binding sites for transporting other essential amino acids. They added that this aspartic acid might excite the brain cells till death.

Holten and Gundersen, 2008 ${ }^{[30]}$ explained the effect of aspartame on the Purkinje cells of the cerebellum to be due to methanol which is one of the components formed from hydrolysis of aspartame. It is converted in the liver to formaldehyde, which is known to be neurotoxin. Formaldehyde lead to increase in the metabolizing enzymes of the cerebellum and also attached to the DNA, RNA and proteins of the cells and became difficult to be removed, which might cause breaks in the DNA causing the changes in the Purkinje cells detected in the present study.

In the present study, the cytoplasm of Purkinje cells in toluidine blue stained sections of cerebellum of Subgroup IIB showed that some Purkinje cells were lightly stained as compared to control group and subgroup IIA with apparent reduction in their Nissl's granules content. This process is called chromatolysis which was explained by Hanz and Fainzilber, 2006 $6^{[31]}$ as the disintegration of the basophilic Nissl bodies. The reaction takes place in the neuronal cytoplasm following traumatic or metabolic injuries.

Mohamed, 2013 ${ }^{[17]}$ observed deeply stained irregular Purkinje cells in the toluidine blue stained sections of 
cerebellar cortex of rats administrated aspartame at a dose of $20 \mathrm{mg}$ /day for 6 months.

In the present work, immunostained sections of subgroup IIA and subgroup IIB revealed apparent increase in the number of GFAP stained astrocytes in all layers of the cerebellar cortex, as compared to control group. This observed increase in the GFAP immunoreaction was confirmed by morphometric and statistical results. There was significant increase in the mean number of positive immunostained astrocytes in both subgroup IIA and subgroup IIB compared to the control group. Also, there was significant increase in the mean number of positive immunostained astrocytes in subgroup IIB in comparison to subgroup IIA.

These findings were in agreement with those of previous research done by Tollefson and Barnard, 1992 ${ }^{[32]}$ who reported that the neuronal damage caused by aspartame could elicit astrocytic proliferation and infiltration.

In agreement with the same results, Abd El-Samad, $2010^{[27]}$ observed increased brownish immunoreaction of the star-shaped cells in-between cells of the granular layer and molecular layer in cerebellum of rats received daily $250 \mathrm{mg} / \mathrm{kgm}$ of aspartame for 8 weeks.

In accordance to our result, Mohamed, 2013 ${ }^{[17]}$ found that the GFAP immunohistochemically stained sections of rats received aspartame at a dose of $20 \mathrm{mg}$ /day for 6 months showed deeply brownish immunoreaction in the star-shaped cells in all layers of cerebellar cortex but it was more in the granular and molecular layers.

Sofroniew and Vinters, 2010 ${ }^{[33]}$ explained that reactive increase in astrocytes is a reliable and sensitive marker of diseased nervous tissue.

In the present work, light microscopic examination of cerebellar cortex of group III showed that Purkinje cells were affected by MSG administration. Examination of H\&E stained sections showed some areas appeared devoid of Purkinje cells. Degenerated Purkinje cells lost their flask shape cell body, became shrunken and distorted in shape. A significant increase was also detected in the mean number of degenerated Purkinje cells in group III when compared to group I and both subgroups of group II.

In accordance to our result, Hashem et al., 2012[11] observed some Purkinje cells of rats received MSG at dose of $3 \mathrm{gm} / \mathrm{kgm}$ body weight for 14 days with darkly stained cytoplasm and shrunken darkly stained nuclei.

Prastiwi et al., 2015 $5^{[34]}$ found a significant decrease of the total number of Purkinje cells of rats administrated MSG at a dosage of $3.5 \mathrm{mg} / \mathrm{gm}$ body weight for 10 consecutive days.

This might be explained by Iamsaard et al., 2014[35] who mentioned that unbound glutamate dissociated from MSG act on certain receptors in the central and peripheral neurons, causing histopathological changes.

Robinson, 2006 ${ }^{[36]}$ reported that the toxic effect of MSG was by altering ionic permeability of neural membrane and induction of persistent depolarization.

In the present study, Examination of toluidine blue stained section of group III (MSG group) showed apparently less Nissl's granules in Purkinje cells so their cytoplasm became pale as compared to control group, while others appeared shrunken and deeply stained.

Similarly, Hashem et al., 2012[1] observed Purkinje cells with darkly stained cytoplasm and shrunken nuclei in toluidine blue stained cerebellar sections of rats received MSG at dose of $3 \mathrm{gm} / \mathrm{kgm}$ body weight for 14 days.

Chromatolysis was previously observed by Alao et al. $2010^{[10]}$ who studied the histological effect of MSG on the frontal cortex of adult Wistar rats.

In the current study, GFAP Immunostained sections of group III revealed an apparent increase in GFAP reaction in astrocytes in all layers of the cerebral cortex, as compared to that seen in the cerebellar cortex of rats in control group. This result was confirmed by morphometric and statistical results; there was significant increase in the mean number of positive immunostained astrocytes in group III when compared with group I and both subgroups of group II. This was previously explained by Sriram et al., 2004 ${ }^{[37]}$ and Baydas et al., 2006 $6^{[38]}$ who reported that any mechanical, chemical or degenerative insult to the brain stimulate astrocyte proliferation and hypertrophy with increase synthesis of GFAP leading to vigorous astrogliosis.

On the contrary, Hashem et al., 2012 $2^{[1]}$ detected nonsignificant increase in GFAP positively stained astrocytes in MSG treated group that received MSG at dose of $3 \mathrm{gm} /$ kgm body weight for 14 days.

In the present work, light microscopic examination of H\&E stained sections of group IV (combination group) showed that all layers of the cerebellar cortex were affected. Purkinje cell layer showed areas devoid of Purkinje cells. Purkinje cells lost their shape and many of them became shrunken and degenerated. Some Purkinje cells of subgroup IVB showed vacuolations in its cytoplasm. Empty spaces in molecular and the granular layers could be detected. Moreover there was significant increase in the mean number of degenerated Purkinje cells in subgroup IVA when compared with group I, both subgroups of group II and group III. Also, significant increase in the mean number of degenerated Purkinje cells was present in subgroup IVB when compared to all groups and subgroups.

Garman, 2011 ${ }^{[39]}$ mentioned that vacuolation within the molecular layer suggesting concurrent swelling/ degeneration of Purkinje neuron dendrites.

Pavlovic et al., 2009[40] explained the effect of MSG on central nervous system as it acts through the activation of glutamate receptor found in the central nervous system. Hyperactivation of these receptors had been reported to produce excitotoxicity and neuronal death.

In the current study, toluidine blue stained sections of both subgroup IVA and subgroup IVB, showed that Purkinje 
cells had apparent reduced Nissl's granules content.

Garman, 2011 ${ }^{[39]}$ described the classic appearance of neuron degeneration as the degenerating neurons characterized at the light microscopic level by cell body shrinkage, loss of Nissl substance, intensely stained eosinophilic cytoplasm, and a small/shrunken darkly stained pyknotic nucleus that may eventually fragment (undergo karyorrhexis).

In the current study, there was significant increase in the mean number of positive immunostained astrocytes in both subgroups IVA and subgroup IVB compared to the all groups and subgroups. Also, there was significant increase in the mean number and area percentage of positive immunostained astrocytes in subgroup IVB in comparison to subgroup IVA.

Barbour et al., 1994[41] mentioned that glutamate and aspartate were taken up by the processes of glial cells that might be an explanation of the increase in the number of GFAP immunostained astrocytes in the cerebellar cortex of both subgroups of group IV (combination group).

The severe degenerative changes detected in the cerebellum of group IV were due to the synergistic effect of aspartame present in Diet Coke and MSG.

Aspartic acid which is also known as aspartate is one of the components of breakdown of aspartame which is an excitatory neurotransmitter in the central nervous system that lead to increase the depolarization of postsynaptic membrane which might cause rapid firing of the neurons as stated by Humphries et al., 2008 ${ }^{[29]}$.

Gill et al., 2000 $0^{[42]}$ explained the neurotoxic effects of MSG by reporting that sustained high concentration of MSG as an excitatory amino acid in the synaptic cleft region resulted in excessive glutamate receptor activation with persistent depolarization producing metabolic and functional exhaustion of the affected neurons leading to neural necrosis.

Bojanic et al., 2004 ${ }^{[43]}$ reported that MSG could act as an "excitotoxin; "as it could overstimulate nerve cells to the point of damage or even death.

\section{CONCLUSION}

It was concluded that Diet Coke and MSG induced degenerative changes in the cerebellar cortex. The use of Diet Coke and MSG in combination causes more significant and had synergistic degenerative effects than their individual intake.

\section{RECOMMENDATIONS}

It is recommended to minimize the intake of Diet Coke and the addition of MSG on food as a taste enhancer as much as possible. Further studies on the effect of both
Diet Coke and MSG either singly or combined on other different organs should be performed.

\section{CONFLICTS OF INTEREST}

The authors have no conflicts of interest to declare.

\section{REFERENCES}

1. Powell LM (2013): Fast food and full service restaurant consumption among children and adolescents. Effect on energy, beverage, and nutrient Intake. JAMA Pediatr; 167(1): 14-20.

2. Fahim A, Ilyas MS and Jafari FA (2015): Histologic effect of carbonated drinks on rat kidney. JRMC; 19(2): 165-167.

3. Lutsey PL, Steffen LM and Stevens J (2008): Dietary intake and the development of the metabolic syndrome: the atherosclerosis risk in communities study. Circulation; 117: 754-761.

4. Otero-Losada ME, Loughlin SM, Granillo GR, Müller A, Ottaviano G, Moriondo M, Cutrin JC and Milei J (2013): Metabolic disturbances and worsening of atherosclerotic lesions in ApoE-/mice after cola beverages drinking. Cardiovasc Diabetol; 12:57

5. Erbaş O, Erdo־gan MA, Khalilnezhad A, Solmaz V, Gürkan FT, Yïgittürk G, Eroglu HA and Taskiran D (2018): Evaluation of long-term effects of artificial sweeteners on rat brain: a biochemical, behavioral, and histological study. J Biochem Mol Toxicol; 32: 1-6.

6. Afeefy A, Mahmoud M and Arafa M (2012): Effect of honey on monosodium glutamate induced nephrotoxicity (histological and electron microscopic studies). J. Am. Sci; 8(1s): 146-156.

7. Mattson MP (2008): Glutamate and neurotrophic factors in neuronal plasticity and disease. Ann N. Y. Acad Sci 1144:97-112..

8. Eweka AO and Om'Iniabohs FAE (2008): Histological Studies of the Effects of Monosodium Glutamate on the Testis of Adult Wistar Rats .The Internet J Urol; 5 (2): 1-5.

9. Win DT (2008): MSG- flavor enhancer or deadly killer. AU J.T; 12(1): 43-49.

10. Alao OA, Ashaolu JO, Ghazal OK and Ukwenya VO (2010): Histological and biochemical effects of monosodium glutamate on the frontal lobe of adult Wistar rats. Int J Biomed and Health Sci; 6 (4): 197-203.

11. Hashem HE, El-Din Safwat MD and Algaidi S (2012): The effect of monosodium glutamate on the cerebellar cortex of male albino rats and 
the protective role of vitamin $\mathrm{C}$ (histological and Immuno-histochemical study). J. Mol. Histol; 43(2): 179-186.

12. Kiyatkin EA (2010): Differential effects of dopamine and opioid receptor blockade on motivated Coca-Cola drinking behavior and associated changes in brain, skin and muscle temperatures. J. Neurosci; 167(2): 439-455.

13. Eluwa MA, Inyangmme II, Akpantah AO, Ekanem TB, Ekong MB, Asuquo OR and Nwakanma AA (2013): A comparative study of the effect of diet and soda carbonated drinks on the histology of the cerebellum of adult female albino Wistar rats. Afr Health Sci; 16: 541-545.

14. Kushawaha S, Malpani A, Aswar UM, Bodhankar SL, Malpani A and Shivakumar S I (2011): Effect of different anaesthetic agents on cardiovascular parameters in male Wistar rats. RJPBCS; 2(2): 685-690

15. Ahmed SK, Kalleny NK, Attia AA and Elkateb LA (2015): The possible protective role of chromium chloride against sodium fluoride induced changes in the structure of the cerebellar cortex of the adult male albino rat. Egypt J Histol; 38 (2): 402-414.

16. Omar SM (2009): Effect of aspartame on the frontal cortex of adult male albino rats. A light and electron microscopic study. Egypt. J. Histol; 32 (2): 346 - 357.

17. Mohamed NA (2013): Chronic effect of aspartame versus stevioside on the cerebellar cortex of the adult albino rat: a histological and immunohistochemical study. Egypt $J$ Histol; 36: 213-232.

18. Eweis DS, Abed F and Stiban J (2017) Carbon dioxide in carbonated beverages induces ghrelin release and increased food consumption in male rats: Implications on the onset of obesity. Obes Res Clin Pract; 11(5): 534-543.

19. Abu-Taweel GM , A ZM, Ajarem JS and Ahmad M (2014): Cognitive and biochemical effects of monosodium glutamate and aspartame, administered individually and in combination in male albino mice. Neurotoxicol Teratol; 42: 60-67.

20. Balbo SL, Mathias PC, Bonfleur ML, Alves HF, Siroti FJ, Monteiro OG, Ribeiro FB and Souza AC (2000): Vagotomy reduces obesity in msgtreated rats. Res Commun Mol Pathol Pharmacol; 108 (5-6): 291-296.

21. Miranda RA, Agostinho AR, Trevenzoli IH, Barella LF, Franco CC, Trombini AB, Malta A, Gravena C, Torrezan R, Mathias PC and de Oliveira JC
(2014): Insulin oversecretion in MSG-obese rats is related to alterations in cholinergic muscarinic receptor subtypes in pancreatic islets. Cell Physiol Biochem; 33(4): 1075-86.

22. Khalaf HA and Arafat EA (2015): Effect of different doses of monosodium glutamate on the thyroid follicular cells of adult male albino rats: a histological study. Int J Clin Exp Pathol; 8(12): 15498-15510.

23. Contini M, Fabro A, Millen N, Benmelej A and Mahieu S (2017): Adverse effects in kidney function, antioxidant systems and histopathology in rats receiving monosodium glutamate diet.Exp Toxicol Pathol; 69(7): 547-556.

24. Alkhedaide A, Soliman MM, Salah Eldin A, Ismail TA, Alshehiri ZS and Attia HF (2016): Chronic effects of soft drink consumption on the health state of Wistar rats: A biochemical, genetic and histopatho-logical study. Mol Med Rep; 13: 5109-5117.

25. Goje LH, Joshua H, Shuaibu I, Ghamba PE, Mafulul SG (2014): Effect of the oral intake of some soft drinks on the fasting blood glucose level and lipid profile of albino rats. Int J Sci; 6(3): 71-75.

26. Kazmi Z, Fatima I, Perveen S and Malik S (2017): Monosodium glutamate: Review on clinical reports. Int J Food Prop; 20 (2): 1807-1815.

27. Abd El-Samad AA (2010): Light and electron microscopic study on the effect of aspartame on the cerebellar cortex of male albino rat. Egypt. J. Histol; 33(3): 419 - 430.

28. Abdul-Hamid $M$ and Gallaly SR (2014): Ameliorative effect of pimpinella anisum oil on immunohistochemical and ultrastuctural changes of cerebellum of albino rats induced by aspartame. Ultrastruct Pathol; 38(3): 224-236.

29. Humphries P, Pretorius E and Naude H (2008): Direct and indirect cellular effects of aspartame on the brain. Eur J Clin Nutri; 62 (4): 451-462.

30. Holten AT and Gundersen V (2008): Glutamine as a precursor for transmitter glutamate, aspartate and GABA in the cerebellum: A role for phosphate-activated glutaminase. J. Neurochem; 104(4): 1032-1042.

31. Hanz S and Fainzilber M (2006): Retrograde signaling in injured nerve - the axon reaction revisited. J Neurochem; 99: 13-19.

32. Tollefson L and Barnard RJ (1992): An analysis of FDA passive Surveillance reports of seizures 
associated with consumption of aspartame. J Am Diet Association; 1: 598- 601.

33. Sofroniew MV and Vinters HV (2010): Astrocytes: biology and pathology. Acta Neuropath; 119: 7-35.

34. Prastiwi D, Djunaidi A and Partadiredja G (2015): High dosage of monosodium glutamate causes deficits of the motor coordination and the number of cerebellar Purkinje cells of rats. Hum Exp Toxicol; 34(11): 1171-1179.

35. Iamsaard S, Sukhorum W, Samrid R, Yimdee J, Kanla P, Chaisiwamongkol K, Hipkaeo W, Fongmoon D and Kondo H (2014):. The sensitivity of male rat reproductive organs to monosodium glutamate. Acta Med Acad; 43(1): 3-9.

36. Robinson MB (2006): Acute regulation of sodiumdependent glutamate transporters: a focus on constitutive and regulated trafficking. Handb.Exp. Pharmacol; (175): 251-275.

37. Sriram K, Benkovic SA, Hebert MA, Miller DB and O'Callaghan JP (2004): induction of gp 130-related cytokines and activation of JAK2/ STAT3 pathway in astrocytes precedes upregulation of glial fibrillary acidic protein in the 1-methyl-4-phenyl-1, 2, 3, 6 tetrahydropyridine model of neurodegeneration: key signaling pathway for astrogliosis in vivo. J Biol Chem; 279: 19936-19947.

38. Baydas G, Ozer M, Yasar A ,Koz ST and Tuzcu M (2006): Melatonin prevents oxidative stress and inhibits reactive gliosis induced by hyperhomocysteinemia in rats. Biochemistry (Mosc); 71(1): 91-95.

39. Garman RH (2011): Histology of the Central Nervous System. Toxicol Pathol.; 39 (1): 22-35.

40. Pavlovic V, Pavlovic D, Kocic G and Sokolovic D (2009): Ascorbic acid modulates monosodium glutamate induced cytotoxicity in rat thymus. Bratisl Lek Listy; 110: 205-9.

41. Barbour B, Keller BU, Llano I and Marty A (1994): Prolonged presence of glutamate during excitatory synaptic transmission to cerebellar Purkinje cells. Neuron; 12: 1331-1343.

42. Gill SS, Mueller RW, Mcguire PF, Pulido OM (2000): Potential target sites in peripheral tissues for excitatory neurotransmission and excitotoxicity. Toxicol Pathol; 28(2): 277-285.

43. Bojanic VV, Bojanic Z, Najman S, Ivanoveurlis J, Tomin J, Dinoic B and Savic T (2004): Diltiazem prevention of monosodium glutamate toxicity on hypothalamus in Wistar rats. Arch Oncol; 12:19-20. 
الملخص العربى

\section{تأثير الايت كولا و جلوتامات أحادي الصوديوم على قشرة مخيخ ذكور

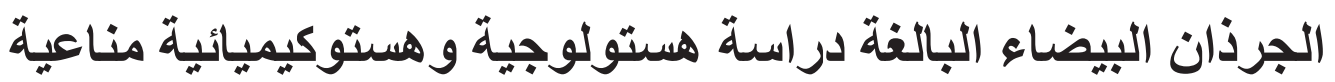

نهى علي عبد اللطيف عبد الواحد، عصمت ذكي غيث، نجوى قسطندي قليني، هدوى علي عبد الخالق قسم الهستولوجيا وبيولوجيا الخلية، كلية الطب، جامعة عين شمس

يتز ايد إستهلاك الوجبات السريعه عند كل من الاطفال ، و المر اهقين و البالغين. ان المشروبات الغازيه مثل الدايت كو لا تستهلك علي نطاق واسع مع الوجبات السريعه. تعد جلوتامات أحادي الصوديو مواحدة من ألاف المو اد الكيميائيه المستخدمه في غذائنا العالي التكنولوجيا. الهذف من البحث: لقد أجريت هذه الدراسة لفحص تأثير الدايت كو لا ، و الجلوتامات أحادي الصوديوم كلاهما معا أو كل على حده على قشرة مخيخ ذكور الجرذان البيضاء البالغة. المواد و الطرق: تم تقسيم أربعون من ذكور الجرذان البيضاء إلى أربع مجموعات. المجموعة الاولى ( المجموعه

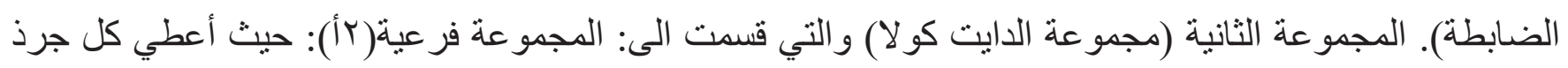
○, rمل من الدايت كولا مرتين يوميا باستخدام أنبوب التغذية عن طريق الفم والمجموعة فرعية(rب):حيث قدمت الدايت كو لا للجرذان لشربها طو ال اليوم وذللك بدلا من الماء.المجموعة الثالثة (مجموعة جلوتامات أحادي الصوديوم) حيث تلقت الجرذان محلول ملح الجلوتامات أحادي الصوديوم( بجرعة سجم /كجم) مرة واحدة يوميا باستخدام أنبوب

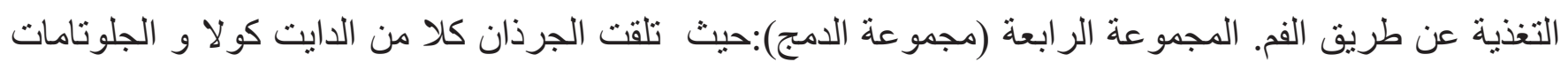
أحادي الصوديوم. قسمت جرذان هذه المجمو عة إلى مجمو عتين فر عييتين. المجمو عة الفرعية( عأ): حيث تلقت الجرذان محلول ملحي من الجلوتامات أحادي الصوديوم بنفس الجرعة كما في المجموعة الثالثة و 0, بمل من الدايت كولا مرتين يوميا ، باستخدام أنبوب التغذية عن طريق الفم. المجمو عة الفرعية(عب): حيث تلقت الجرذان محلول ملحي من الجلوتامات أحادي الصوديوم بنفس الجرعة كما في المجموعة الثالثة و الدايت كو لا لثربها بدلا من الماء طو ال اليوم. في نهاية التجربة ( آيوما) تم تشريح عينات المخيخ و إعدادها للار اسات الهيستولوجيه و الهيستوكيميائيه المناعيه و الدر اسات القياسية.

النتائج: أظهر الفحص الهيستولوجي لقترة المخيخ أن الدايت كولا و الجلوتامات أحادي الصوديوم كلاهما معا أو كل على حده نتج عنه تغبير ات تتكسية كانت أكثر وضوحا في مجمو عة الدمج. الاستنتاج: تسبيت الدايت كو لا و الجلوتامات أحادي الصوديوم في حدوث تغير ات تنكسية في قثرة المخيخ وقد كانت أكثر وضوحا عند الجمع بينهما. 